\title{
Benthic macroinvertebrates and degradation of phytomass as indicators of ecosystem functions in flooded rice cropping
}

\author{
Lilian Terezinha Winckler ${ }^{(1)}$, Angélica Konradt Güths ${ }^{(2)}$ and Pâmela Rodrigues Gayer ${ }^{(3)}$
}

\begin{abstract}
(1)Embrapa Clima Temperado, Rodovia BR-392, Km 78, 9 Distrito, Monte Bonito, CEP 96010-971 Pelotas, RS, Brazil. E-mail: lilian.winckler@embrapa.br (2)Universidade Federal de Pelotas, Rua Gomes Carneiro, o 01, Campus Porto, CEP 96010-610 Pelotas, RS, Brazil. E-mail: angelica-kg1@hotmail.com ${ }^{(3)}$ Instituto Federal Sul-rio-grandense, Praça Vinte de Setembro, no 455, Campus Pelotas, CEP 96015-360 Pelotas, RS, Brazil. E-mail: pamrgayer@hotmail.com
\end{abstract}

\begin{abstract}
The objective of this work was to evaluate the ecosystem functions of a natural wetland and of artificially flooded rice areas, managed under organic and conventional systems, by phytomass degradation and by the colonization of this material by benthic macroinvertebrates. The experiment was carried out in a natural wetland area, and in two flooded rice areas managed under organic and conventional systems. Twenty-five decomposition bags filled with $10 \mathrm{~g}$ of dry vegetation were installed in each site. At 14, 28, 42, 56, and 70 days after the beginning of the experiment, five bags from each site were collected. Macroinvertebrates were identified and classified by functional trophic group. The number of species of benthic macroinvertebrates increased: natural wetland $>$ organic system $>$ conventional system. The Chironomidae group was present in all areas, confirming its food plasticity and adaptability to different substrates and environmental stress situations. The Amphipoda group was present only in the artificially flooded rice area, and the Acari, only in the natural wetland. The diversity of species in the natural wetland area was higher than in the artificially flooded rice area. Nutrient cycling, provided by phytomass decomposition, is affected by the management system, and the delay in this process causes a reduction of the ecosystem functions in the conventional system.
\end{abstract}

Index terms: Oryza sativa, Aqualf, biomass degradation, ecosystem services, nutrient cycling, paddy soils.

\section{Macroinvertebrados bentônicos e degradação da fitomassa como indicadores de funções ecossistêmicas em arroz irrigado por inundação}

Resumo - O objetivo deste trabalho foi avaliar as funções ecossistêmicas de um banhado natural e de lavouras de arroz irrigado por inundação, manejadas nos sistemas convencional e orgânico, por meio da degradação da fitomassa e da colonização desse material por macroinvertebrados bentônicos. O experimento foi realizado em um banhado natural e em duas áreas de arroz irrigado por inundação, manejadas em sistemas orgânico e convencional. Vinte e cinco bolsas de decomposição, cada uma preenchida com $10 \mathrm{~g}$ de palha seca, foram instaladas em cada local. Aos 14, 28, 42, 56 e 70 dias após o início do experimento, cinco bolsas de cada local foram retiradas. Os macroinvertebrados foram identificados e classificados por grupo trófico funcional. $\mathrm{O}$ número de espécies de macroinvertebrados bentônicos aumentou: banhado natural $>$ sistema orgânico > sistema convencional. O grupo Chironomidae estava presente em todas as áreas, o que confirma sua plasticidade alimentar e adaptabilidade a diferentes substratos e situações de estresse ambiental. $\mathrm{O}$ grupo Amphipoda esteve presente somente nas lavouras de arroz artificialmente inundadas, enquanto o grupo Acari, somente no banhado natural. A diversidade de espécies no banhado natural foi maior do que nas áreas de arroz artificialmente inundadas. A ciclagem de nutrientes, por meio da degradação da fitomassa, é influenciada pelo sistema de manejo, e o atraso nesse processo reduz as funções do ecossistema no sistema convencional.

Termos para indexação: Oryza sativa, Planossolos, degradação da biomassa, serviços ecossistêmicos, ciclagem de nutrientes, solos de várzea.

\section{Introduction}

Remaining flooded rice straw and post-harvest sprouts (traditionally developed in rice regrowth, in the southern end of Rio Grande do Sul) are important as fodder for livestock (Monks et al., 2002). Straw degradation ensures a gradual supply of significant amount of nutrients to crop in succession in well managed systems (Massoni et al., 2013). In addition, if the area is replanted, a rapid elimination of straw is necessary in rice cultivation, to allow of planting to be carried out in a timely manner within the recommended period (Massoni et al., 2013). 
Irrigated soils for rice cultivation, comprising humid or waterlogged environments, have a poor drainage (Monks et al., 2002) which persists after harvest. In those wet environments, decomposition can be divided into the three following phases: leaching, which releases water-soluble organic and inorganic compounds that are important for microbial and phytoplanktonic metabolism; conditioning or catabolism, which involves colonization by microorganisms, mainly bacteria and fungi that will macerate, metabolize, and embed leaves for secondary production, as well as increase of the palatability and nutritional value of litter; and fragmentation that can be carried out biologically by detritivorous macroinvertebrates, other microorganisms, or physical fragmentation (CunhaSantino \& Bianchini Jr., 2006; Gimenes et al., 2010).

In wetlands, benthic macroinvertebrates are responsible for sediment biorevolving, releasing nutrients into water, and accelerating the cycling process. They have an important role in the trophic dynamics, and constitute the link between the grower and the consumer, by performing filtering, fragmentation, and scraping of food, processing and converting it into phytomass available for other organisms, as well as assisting in the decomposition process (Nin et al., 2009; Oliveira \& Callisto, 2010). These organisms are components of the biological diversity of natural as well as artificial wetlands, which include agroecosystems of flooded rice fields. They perform important ecosystem functions (Melo et al., 2015), by carrying through the ecosystem services in these areas. According to Groot et al. (2002), an ecosystem function is the ability of natural process and components to provide goods and services that satisfy human needs either directly or indirectly. Therefore, the nutrient cycling process is linked to the provision of ecosystem regulation services. Studies conducted in different regions have shown the biodiversity importance of soil organisms on the maintenance and distribution of other ecosystem services, which requires the understanding of occurrence patterns of these mechanisms, in different ecosystems, and the types of functional microorganisms (Bardgett \& Putten, 2014; Handa et al., 2014).

For Silveira et al. (2012), irrigated rice production in Rio Grande do Sul is characterized by highly technicalized production; therefore, pesticides are used to prevent invasive plants, insects, and diseases from damaging the production. Chemicals cause ecological risks to different organisms, and the use of conjugate products, which is common in cultural practices, results in additive actions between them, even for less toxic ones (Nakagome et al., 2007). This technicalization arises from conventional rice growing systems, in contrast to organic production systems of irrigated rice, which not only are performed without the use of pesticides and synthetic fertilizers, but also are based on crop rotation (Wilson et al., 2008).

Species diversity and functional redundancy of the microorganisms responsible for providing these processes are ecological strategy keys to bring stability to the system and sustainability to the crop (Thrupp, 2000). Thus, the degradation process can provide important information on ecosystem functionality (Telöken et al., 2011), and can help in the definition of a sustainable management.

The objective of this work was to evaluate the ecosystem functions of a natural wetlands and of artificially flooded rice areas, managed under organic and conventional systems, by phytomass degradation and by the colonization of this material by benthic macroinvertebrates.

\section{Materials and Methods}

The experiment was carried out in the municipality of Santa Vitória do Palmar, RS, at $10 \mathrm{~m}$ altitude, Brazil $\left(32^{\circ} 45^{\prime} 00^{\prime \prime} \mathrm{S} ; 52^{\circ} 38^{\prime} 54^{\prime \prime} \mathrm{W}\right)$, one of the largest flooded rice growing areas in the country. The climate of the region is characterized by a $\mathrm{Cfa}$ (humid subtropical), according to the classification by Köppen-Geiger, with an average annual temperature of $16^{\circ} \mathrm{C}$, and precipitation between 1,800 and 2,200 $\mathrm{mm}$ (Kottek et al., 2006).

Rice is sown between September and November in the region. A minimum cultivation is applied under conventional systems, which involves the previous desiccation of vegetation by a nonselective herbicide for direct seeding. The seeding occurred in October 2013, and seed were treated to prevent infestation by Oryzophagus oryzae. Organic farming requires soil preparation in the planting period, which eventually causes delays, due to the possible entry of machinery in the field. In the studied site, sowing occurred in late November 2013. In the conventional system, $60 \mathrm{~kg} \mathrm{ha}^{-1} \mathrm{P}_{2} \mathrm{O}_{5}$ and $\mathrm{K}_{2} \mathrm{O}$ were added in the planting, 
and, for fertilization, $150 \mathrm{~kg} \mathrm{ha}^{-1} \mathrm{~N}$ was applied in the differentiation of the flowering event. There was no fertilization in the organic system, except for the residual fertilization used on pasture, which consisted of $200 \mathrm{~kg} \mathrm{ha}^{-1}$ natural phosphate. Irrigation started for both systems at the three-to-four leaf stage (V3/V4), and water blade was kept around $10 \mathrm{~cm}$. Rice under conventional system was harvested in February 2014, and under the organic system, in March 2014.

To evaluate the proposed systemic functions (Table 1), 20x15 cm decomposition bags were made with a combination of mesh spacing. One side was made of $0.5 \mathrm{~cm}$ mesh between knots, and the other, of $0.1 \mathrm{~cm}$ mesh, as proposed by Carvalho \& Ueida (2009). The bags were filled with $10 \mathrm{~g}$ rice straw, collected in the experimental station site Terras Baixas of Embrapa Clima Temperado, and straw was oven-dried at $60^{\circ} \mathrm{C}$ until constant weight was obtained.

The experiment was conducted between May 26 and August 4, 2014, in three different management systems: organic rice farming; conventional farming; and a natural wet site (natural wetland vegetation) in the surroundings of the cultures (Figure 1). Seventyfive decomposition bags were introduced -25 bags each system -, which were fixed at stakes and equally distributed in five points in each system.

At installation and during the collections of the decomposition bags, four physical and chemical water parameters were monitored: $\mathrm{pH}$ ( $\mathrm{pHmetro}$ Digimed DM2P), conductivity (conductivity meter Digimed DM3P), temperature (mercury thermometer), and height of water blade (graduated ruler).

At 14, 28, 42, 56, and 70 days, five bags were individually removed from each site, and were warped with a $0.05 \mathrm{~mm}$ mesh to prevent loss of plant material and organisms. In the field, the bags were stored in plastic bags, and sent to a laboratory at Embrapa Clima Temperado, where they were opened and washed in running water in $850 \mu \mathrm{m}$ and $250 \mu \mathrm{m}$ sieves.

Retained biomass in the $850 \mu \mathrm{m}$ sieve was stored in paper bags, which were labeled and oven-dried at $60^{\circ} \mathrm{C}$ until constant weight was attained; then,

Table 1. Ecosystem services obtained by processes and functions from organisms in the soil-water interface, assessed according to Groot el al. (2002).

\begin{tabular}{lccc}
\hline Ecosystem functions & Ecosystem process & Assessment & Ecosystem goods and services \\
\hline 1. Regulation & Nutrient cycling & Biomass degradation & $\begin{array}{c}\text { Maintenance of soil health and productive } \\
\text { ecosystems }\end{array}$ \\
2. Habitat & Habitat provision & $\begin{array}{c}\text { Diversity of families and functional trophic } \\
\text { groups }\end{array}$ & Maintenance of biological diversity \\
\hline
\end{tabular}

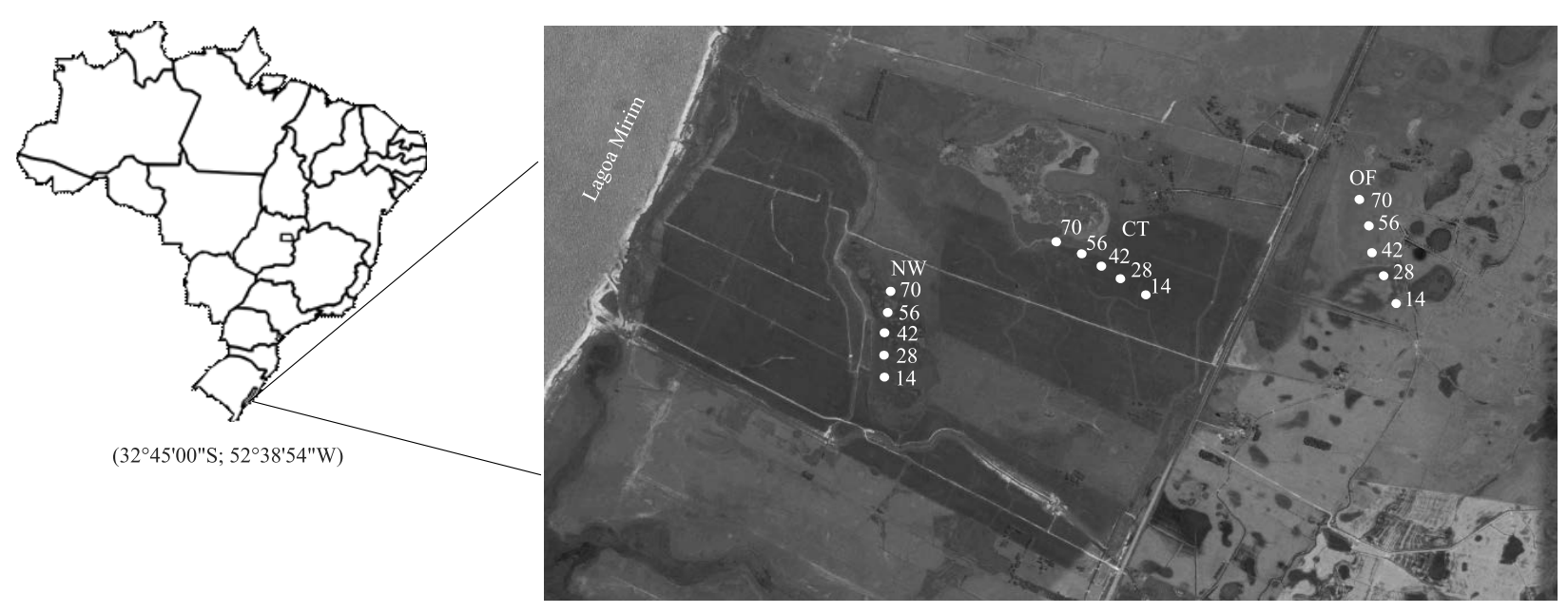

Figure 1. Map of the experimental sites in Santa Vitória do Palmar, state of Rio Grande do Sul, Brazil: NW, natural wetland area; CT, conventional systems; and OF, organic systems, and the points from which five units were sampled, in each site, are described according to the collecting day after the incubation, at $14,28,42,56$, and 70 days. 
they were weighed on an analytical balance. Benthic macroinvertebrates sorted from the material retained in the sieves were identified under a stereomicroscope using a suitable identification key (Mugnai et al., 2010), and after this procedure, they were recorded, and stored in $70 \%$ alcohol.

Functional trophic groups (FTG) of the sampled benthic macroinvertebrates were categorized according to the classification proposed by Cummins et al. (2005) and to supplementary bibliography (Mormul et al., 2006; Oliveira \& Callisto, 2010; Barbola et al., 2011; Santos, 2014; Telöken et al., 2014; Santos \& Rodrigues, 2015).

The diversity index of Shannon-Wiener was calculated by the program Dives 3.0 (Rodrigues, 2014), and the occurrence constancy was calculated by the equation $\mathrm{C}=[$ (number of samples with species/total number of samples) $\times 100]$. Constant species occurred in $50 \%$ or more of the samples, accessory ones in the range between 25 and $50 \%$ of samples, and incidental species occurred in less than $25 \%$ of the samples.

The model of Petersen \& Cummins (1974) was used to calculate the percentage of remaining biomass $(\% \mathrm{R})$ and biomass decay coefficient $(\mathrm{k})$, according to the respective equations $\% \mathrm{R}=(\mathrm{Wt} / \mathrm{W} 0) \times 100$, and $\mathrm{k}=-(1 / \mathrm{t}) \times \ln (\mathrm{Wt} / \mathrm{W} 0)$, in which: Wt is the biomass weight at the time of observation; W0 is the initial biomass weight, and the decay coefficients are classified as slow, when $\mathrm{k}<0.005$ per day, or fast, when $\mathrm{k}>0.010$ per day.

The correlation analysis between the physicochemical parameters and the organisms in the studied sites was conducted using the Mantel test, with the Multiv program (Pillar, 2001), and the rope distance was considered as a similarity measure. The randomization test (Pillar \& Orlóci, 1996), carried out with the Multiv program, was used to evaluate the differences $(p<0.05)$ of the physicochemical data of water, biomass degradation, abundance of benthic macroinvertebrates, as well as the diversity index between the studied sites. The Euclidean distance was used as a similarity measure for biotic parameters, and, the Gower index, for the abiotic parameters, without performing data transformation. The correlations between biomass decay and the diversity index, biomass decay and abundance, and biomass decay and the number of functional trophic groups were also evaluated for straw from organic and conventional farmings, and from the natural wetland vegetation $(\mathrm{p}<0.05)$.

\section{Results and Discussion}

There was no difference $(\mathrm{p}>0.05)$ for water physicochemical parameters between the three sampled sites. Electric conductivity showed a great variation, and the highest values were observed in the conventional farming (Table 2). Chemical inputs used in conventional management may have affected this difference; the organic farming does not make use of these inputs (Wilson et al., 2008). No correlation was observed between the physicochemical and biotic parameters ( $\mathrm{p}>0.05)$ (Figure 2).

During the experimental period, 4,259 specimens of benthic macroinvertebrates were found, as follows: 335 specimens in the conventional system, distributed in 18 taxa (1 phylum, 1 class, 3 orders, and 13 families); 630 specimens in the organic farming, distributed across 14 taxa (1 phylum, 1 class, 1 subclass, 3 orders, and 8 families); and 3,294 specimens in the natural wetland, distributed in 27 taxa (1 phylum, 1 class, 1 subclass, 3 orders, and 21 families) (Table 3 ).

Using decomposition bags in a lentic environment, in the southern end of Rio Grande do Sul state, Telöken et al. (2011) found a greater abundance of organisms than that found in the present study. However, despite the proximity of the sampled sites, this work was conducted in the winter, while Telöken et al. (2011) performed theirs in the autumn with an average temperature of $23.95^{\circ} \mathrm{C}$, which may have affected these differences, as well as the differences between the evaluated plant species (Carvalho \& Uieda, 2009; Gimenes et al., 2010).

The abundance of benthic macroinvertebrates was higher $(p<0.05)$ in the natural wetland than in the cultivated fields, which is opposite to what was reported by Pires et al. (2015), who evaluated irrigated rice farmings during the crop season, and reported drought problems at the time of the study. In the present work, abundancy in the site of the organic farming was higher $(p<0.05)$ than in the conventional one, in accordance with the results obtained by Wilson et al. (2008) during the crop season.

The diversity index showed variation over the period, and its were higher $(\mathrm{p}<0.05)$ at days 14,28 , and 56 than those observed at days 42 and 70. The management systems showed that the diversity index in the conventional cultivation was lower $(p<0.05)$ than that observed for the natural wetland. However, the diversity index for the organic systems did not 
differ from that in the other sampled sites. The results were different from those observed in rice fields in Australia, where the organic cultivation showed higher diversity indices throughout the experimental period (Wilson et al., 2008). Keeping diversity is a feature of more sustainable systems (Thrupp, 2000), which increases redundancy of microorganisms performing the same systemic functions (for example, more organisms of a single trophic group); this allows of organisms to carry out the processes, and ensure maintenance of the ecosystem functions, even if some of these organisms decrease, due to their sensitivity to some environmental factors.

According to Pires et al. (2015), the fauna recorded in the conventional system is usually rich and diversified; however, it is characterized by a high ecological dynamism, and by its composition of environmental disturbance-tolerant groups, with a high capacity for colonization. During the sampling period, sensitive organisms to environmental changes, such as Ephemeroptera (Kerans \& Karr, 1994) were not found in the conventional systems, which corroborates data of Pires et al. (2015).

The occurrence frequency (Table 4) showed that the organisms were distributed in the fields as follows: in the conventional system, Chironomidae and Amphipoda; in the organic system, Hirudinea, Chironomidae, Nematoda, and Amphipoda; and, in the natural wetland, Hirudinea, Acari, Chironomidae, Nematoda, and Collembola. Chironomidae were present in all studied areas. Colonization in decomposition bags by this family has been observed by various authors, underscoring its dominance both in lotic and lentic environments (Moulton \& Magalhães, 2003; Mormul et al., 2006). This situation probably occurs because Chironomidae show great food plasticity, and high adaptive power to different substrates, and to different situations of environmental stress. This group is important for the leaf degradation processes in the litter with low nutritional value, and absence of shredders (Moretti et al., 2007).
The Amphipoda group was constant only in the conventional and organic systemss, while Acari occurred only in the natural wetland. For Nin et al. (2009), colonization by amphipods starts in the first hours of exposure, and it is later replaced by other groups, especially insects. Santos \& Rodrigues (2015) observed that over time there is an increase of colonization and succession of smaller organisms, such as mites. Considering that the colonization by shredders in the natural wetland occurred before the first collection, these herbivores (shredders) were replaced by detritivores (collectors), and these, by carnivores (predators). From these predators, Acari were the major representatives in the natural wetland, while Nematoda were predominant in the cultivated fields. Probably, this distribution is due to Acari sensitivity to physical disorders (Di Sabatino et al., 2000), according to the sensitivity range of macroinvertebrate families of Costa Rica (Rizo-Patrón V. et al., 2013). The comparison of the occurrence frequency (Table 4) with this scale showed that in the conventional rice cultivation, accessory and constant families are the only ones classified as sensitivity 3 . In the conventional management, in addition to these families, Haliplidae with sensitivity 4 occurred. In the wetland, accessory and constant families were Acari and Caenidae, with sensitivity 4.

Among the functional trophic groups (FTG), removed from the bags at the day 14 , the presence of shredders was observed in the conventional system, and predators were prevalent, followed by collectors (Figure 2). During this period, the number of shredders in the conventional system increased, and FTG were dominant in this management system, in comparison to the others. FTG succession was apparently faster in the organic farming and in the natural wetland than in the conventional system. In the natural wetland, detritivores appeared in a greater proportion at the day 14; and, in the organic management, they appeared at the day 28 , gradually increasing after this period. For Telöken et al. (2011), despite the high correlation of shredders

Table 2. Mean values and standard deviation of physical and chemical parameters by the time of sample collection ${ }^{(1)}$.

\begin{tabular}{lcc}
\hline Site & Condutivity $\left(\mu \mathrm{S} \mathrm{cm}{ }^{-1}\right)$ & Temperature $\left({ }^{\circ} \mathrm{C}\right)$ \\
\hline Organic system & $105.04 \mathrm{a}(39.56)$ & $13.4 \mathrm{a}(1.35)$ \\
Conventional system & $515.78 \mathrm{a}(292.35)$ & $12.8 \mathrm{a}(1.85)$ \\
Natural wetland & $142.36 \mathrm{a}(37.90)$ & $14.4 \mathrm{a}(10.46)$ \\
\hline
\end{tabular}

${ }^{(1)}$ Values followed by equal letters, in the lines, show no significant difference, at $5 \%$ probability. The standard deviation is described in parentheses. 

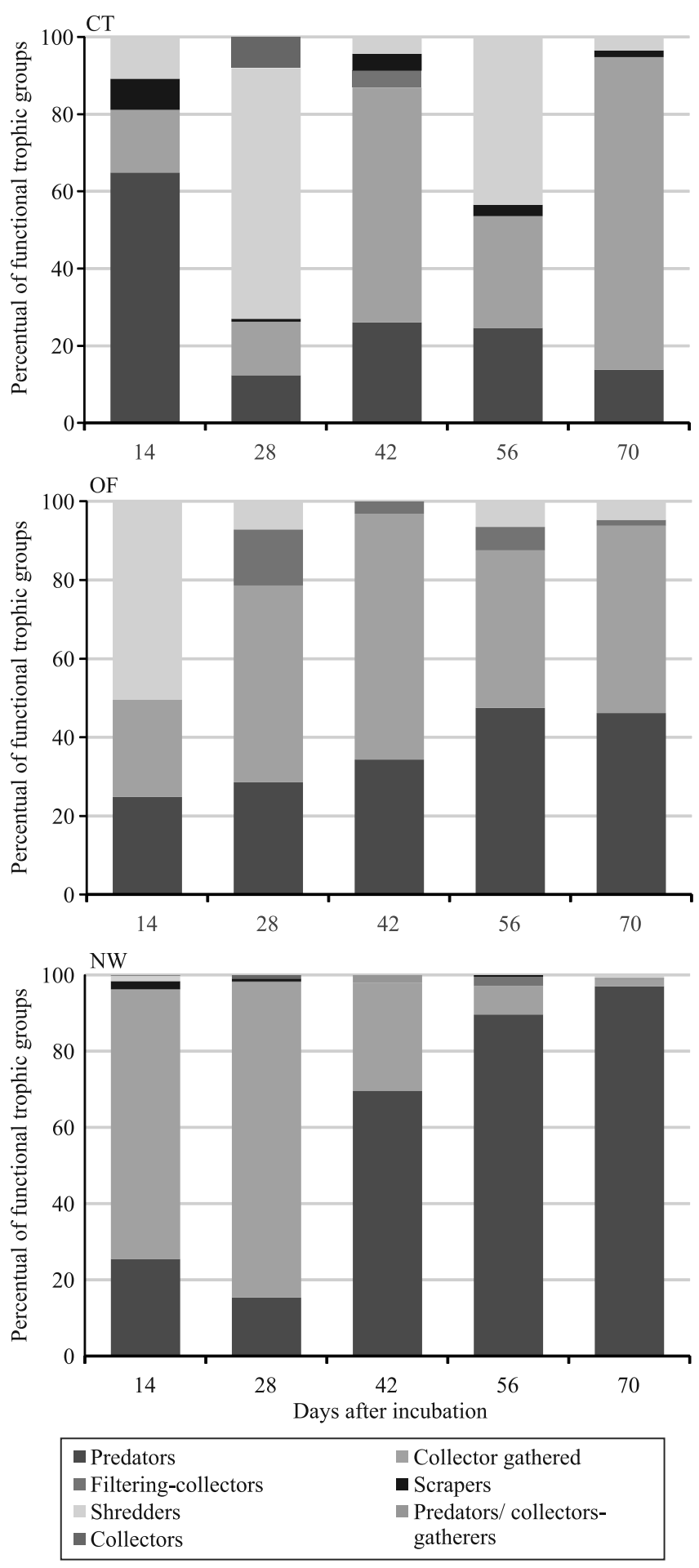

Figure 2. Percentual of functional trophic groups (predators; collector; filtering-collectors; scrapers; shredders; predators/ collectors-gatherers; collectors) found in the sampled sites at $14,28,42,56$, and 70 days after the beginning of incubation. CT, conventional system; OF: organic system; and NW, natural wetland. with foliar degradation rate in temperate regions, the contributions of this FTG for the litter decomposition in subtropical areas have been smaller than in areas of higher latitudes. This was also observed in the present study; however, the first evaluation occurred only at the day 14. Shredders might have occurred in the first two weeks, mainly in the organic cultivation and in the natural wetland; however, in the late collection period, they were not detected. After this period, shredders were replaced by carnivores and omnivores in the natural wetland and in the organic cultivation, while detritivores reached a higher proportion between FTG in the conventional system only at the day 70 . The great presence of predators and parasites occurs probably by the availability of potential prey (Mormul et al., 2006). The number of functional trophic groups showed no significant correlation with decay of foliar biomass, which is probably due to this dynamic in colonization.

The different management systems were equivalent as for biomass loss; however, there was interaction between time and management systems. There was difference between the conventional and the other management system at 14 and 28 days after incubation $(\mathrm{p}<0.05)$ (Figure 3). According to the decay coefficient, proposed by Petersen \& Cummins (1974), the results in all periods and management systems were greater than 0.010 per day, which expresses a quick biomass decay.

In the present study, there was a fast biomass decay, which was more expressive at the day 40 , mainly in the natural wetland that showed a greater richness during this period, indicating that the action of these organisms was effective for biomass decomposition. There was no correlation between diversity and biomass degradation in the organic cultivation and in the natural wetland, while in the conventional system, this correlation was significant. Probably the redundancy between groups makes diversity greater than the minimum required to keep this ecosystem functioning (Moulton et al., 2003), both in the organic system and in the natural wetland. However, for the conventional system, this diversity is smaller, and any variation is related to losses in the ecosystem function. Our results on degradation agree with those reported by Telöken et al. (2011), which had greatest biomass losses in the initial phase, with a trend to stabilization that extends from the day 32 until the end of the experiment, at day 71 . 
Abundance did not correlate with biomass decay wetland, showing that the benthic macroinvertebrates in the systems, but it was significant for the natural in cultivation areas were probably affected, having

Table 3. Abundance of benthic macroinvertebrates found in bags of foliar degradation in the areas of conventional (CT) and organic systems (OF) residues, and on the area of the natural wetland (NW), at 14, 28, 42, 56, and 70 days after the introduction of degradation bags, and their respective functional trophic group (FTG).

\begin{tabular}{|c|c|c|c|c|c|c|c|c|c|c|c|c|c|c|c|c|}
\hline \multirow[t]{2}{*}{ Taxon } & \multirow[t]{2}{*}{ FTG $^{(1)}$} & \multicolumn{3}{|c|}{ DAY 14} & \multicolumn{3}{|c|}{ DAY 28} & \multicolumn{3}{|c|}{ DAY 42} & \multicolumn{3}{|c|}{ DAY 56} & \multicolumn{3}{|c|}{ DAY 70} \\
\hline & & $\mathrm{CT}$ & $\mathrm{OF}$ & NW & $\mathrm{CT}$ & OF & NW & $\mathrm{CT}$ & OF & NW & $\mathrm{CT}$ & $\mathrm{OF}$ & NW & $\mathrm{CT}$ & OF & $\mathrm{NW}$ \\
\hline Nematode & $\mathrm{P}$ & 8 & 19 & 108 & 0 & 4 & 10 & 0 & 0 & 11 & 14 & 89 & 65 & 1 & 88 & 107 \\
\hline \multicolumn{17}{|l|}{ Diptera } \\
\hline Ceratopogonidae & $\mathrm{P} / \mathrm{Cc}$ & 0 & 0 & 1 & 0 & 0 & 0 & 0 & 0 & 8 & 0 & 0 & 0 & 0 & 0 & 0 \\
\hline Chaoboridae & $\mathrm{P}$ & 2 & 0 & 0 & 0 & 0 & 0 & 0 & 0 & 0 & 0 & 0 & 0 & 0 & 0 & 0 \\
\hline Chironomidae & $\mathrm{Cc}$ & 0 & 19 & 270 & 15 & 19 & 331 & 14 & 19 & 109 & 20 & 86 & 11 & 47 & 100 & 7 \\
\hline Culicidae & $\mathrm{C}$ & 0 & 0 & 3 & 11 & 0 & 6 & 0 & 0 & 0 & 0 & 0 & 0 & 0 & 0 & 0 \\
\hline Sciomyzidae & $\mathrm{P}$ & 0 & 0 & 0 & 5 & 0 & 0 & 0 & 0 & 0 & 0 & 0 & 0 & 0 & 0 & 0 \\
\hline Syrphidae & $\mathrm{Cf}$ & 0 & 0 & 2 & 0 & 0 & 0 & 0 & 0 & 0 & 0 & 0 & 0 & 0 & 0 & 0 \\
\hline Tabanidae & $\mathrm{P}$ & 1 & 0 & 0 & 1 & 0 & 0 & 0 & 0 & 0 & 0 & 0 & 0 & 0 & 0 & 0 \\
\hline Tipulidae & $P$ & 0 & 0 & 2 & 0 & 0 & 0 & 0 & 0 & 0 & 0 & 0 & 0 & 0 & 0 & 0 \\
\hline \multicolumn{17}{|l|}{$\overline{\text { Coleoptera }}$} \\
\hline Dytiscidae & $P$ & 1 & 1 & 2 & 1 & 0 & 0 & 3 & 0 & 0 & 0 & 0 & 0 & 0 & 0 & 0 \\
\hline Elmidae (immature) & $\mathrm{Cc}$ & 0 & 0 & 0 & 0 & 0 & 0 & 0 & 0 & 0 & 0 & 0 & 0 & 0 & 0 & 1 \\
\hline Elmidae (adult) & $\mathrm{R}$ & 0 & 0 & 0 & 0 & 0 & 1 & 0 & 0 & 0 & 0 & 0 & 0 & 0 & 0 & 0 \\
\hline Gyrinidae & $\mathrm{P}$ & 0 & 0 & 0 & 0 & 0 & 6 & 0 & 0 & 0 & 0 & 0 & 1 & 0 & 0 & 0 \\
\hline Haliplidae & $\mathrm{Cf}$ & 0 & 0 & 0 & 0 & 2 & 0 & 1 & 1 & 0 & 0 & 12 & 0 & 0 & 3 & 0 \\
\hline Hydrophilidae (immature) & $\mathrm{P}$ & 0 & 0 & 0 & 0 & 0 & 2 & 0 & 0 & 0 & 0 & 0 & 0 & 1 & 0 & 0 \\
\hline Hydrophilidae (adult) & $\mathrm{Cc}$ & 0 & 0 & 1 & 0 & 0 & 0 & 0 & 0 & 0 & 0 & 0 & 0 & 0 & 0 & 0 \\
\hline Hydropsychidae & $\mathrm{Cf}$ & 0 & 0 & 0 & 0 & 0 & 0 & 0 & 0 & 0 & 0 & 1 & 0 & 0 & 0 & 0 \\
\hline \multicolumn{17}{|l|}{ Hemiptera } \\
\hline Corixidae & $\mathrm{R}$ & 0 & 0 & 25 & 0 & 0 & 0 & 0 & 0 & 0 & 0 & 0 & 0 & 0 & 0 & 0 \\
\hline Hebridae & $\mathrm{P}$ & 0 & 0 & 1 & 0 & 0 & 0 & 0 & 0 & 0 & 0 & 0 & 0 & 0 & 0 & 0 \\
\hline Hydrometridae & $\mathrm{P}$ & 0 & 0 & 0 & 0 & 1 & 0 & 1 & 0 & 0 & 0 & 0 & 0 & 0 & 0 & 0 \\
\hline Mesoveliidae & $P$ & 0 & 0 & 0 & 0 & 0 & 7 & 0 & 0 & 0 & 0 & 0 & 1 & 0 & 0 & 0 \\
\hline Saldidae & $\mathrm{P}$ & 0 & 0 & 0 & 0 & 0 & 3 & 0 & 0 & 0 & 0 & 0 & 0 & 0 & 0 & 0 \\
\hline Veliidae & $P$ & 0 & 0 & 2 & 0 & 0 & 1 & 0 & 0 & 0 & 0 & 0 & 0 & 0 & 0 & 0 \\
\hline \multicolumn{17}{|l|}{$\overline{\text { Odonata }}$} \\
\hline Calopterigidae & $\mathrm{P}$ & 0 & 0 & 1 & 0 & 0 & 1 & 0 & 0 & 0 & 0 & 0 & 0 & 0 & 0 & 0 \\
\hline Libellulidae & $\mathrm{P}$ & 0 & 1 & 1 & 0 & 0 & 2 & 1 & 0 & 0 & 0 & 0 & 0 & 0 & 0 & 0 \\
\hline \multicolumn{17}{|l|}{ Ephemeroptera } \\
\hline Baetidae & $\mathrm{Cc}$ & 0 & 0 & 0 & 0 & 0 & 0 & 0 & 0 & 0 & 0 & 1 & 0 & 0 & 0 & 0 \\
\hline Caenidae & $\mathrm{Cc}$ & 0 & 5 & 7 & 0 & 2 & 15 & 0 & 0 & 3 & 0 & 0 & 3 & 0 & 0 & 0 \\
\hline Leptohyphidae & $\mathrm{Cc}$ & 0 & 0 & 2 & 0 & 0 & 0 & 0 & 0 & 0 & 0 & 0 & 0 & 0 & 0 & 0 \\
\hline \multicolumn{17}{|l|}{ Trichoptera } \\
\hline Xyphocentronidae & $\mathrm{Cc}$ & 0 & 0 & 1 & 0 & 0 & 0 & 0 & 0 & 0 & 0 & 0 & 0 & 0 & 0 & 0 \\
\hline Collembola & $\mathrm{Cc}$ & 6 & 8 & 877 & 4 & 0 & 186 & 0 & 1 & 1 & 0 & 0 & 2 & 0 & 0 & 0 \\
\hline Hirudinea & $\mathrm{P}$ & 8 & 7 & 28 & 5 & 7 & 21 & 0 & 11 & 34 & 2 & 12 & 34 & 6 & 9 & 28 \\
\hline Amphipoda & $\mathrm{F}$ & 4 & 65 & 22 & 89 & 3 & 0 & 1 & 0 & 0 & 30 & 14 & 0 & 2 & 10 & 3 \\
\hline \multicolumn{17}{|l|}{ Decapoda } \\
\hline Palaemonidae & $\mathrm{F}$ & 0 & 0 & 0 & 0 & 0 & 0 & 0 & 0 & 0 & 0 & 0 & 0 & 1 & 0 & 0 \\
\hline Acari & $\mathrm{P}$ & 4 & 4 & 274 & 5 & 0 & 46 & 1 & 0 & 232 & 1 & 2 & 89 & 0 & 0 & 263 \\
\hline Bivalvia & $\mathrm{Cf}$ & 0 & 0 & 1 & 0 & 4 & 1 & 0 & 0 & 0 & 0 & 0 & 5 & 0 & 0 & 1 \\
\hline \multicolumn{17}{|l|}{$\overline{\text { Gastropoda }}$} \\
\hline Planorbidae & $\mathrm{R}$ & 3 & 0 & 1 & 1 & 0 & 3 & 1 & 0 & 0 & 2 & 0 & 0 & 1 & 0 & 0 \\
\hline Physidae & $\mathrm{R}$ & 0 & 0 & 9 & 0 & 0 & 1 & 0 & 0 & 0 & 0 & 0 & 1 & 0 & 0 & 0 \\
\hline Total & & 37 & 129 & 1641 & 137 & 42 & 643 & 23 & 32 & 398 & 69 & 217 & 212 & 59 & 210 & 410 \\
\hline
\end{tabular}

(1)P, predators; C, collectors; Cc, collector-gatherer; Cf, filtering-collectors; F, shredders; and R, scrapers. 
their contribution this process decreased in this changed environment. Degradation stability and decrease of the macroinvertebrate abundance, from day 42 after incubation on, may be related to rice straw composition. From that period on, straw may contain compounds of difficult degradation, such as lignin and polyphenols, which would prevent the direct action of macroinvertebrates. According to Moretti et al.

Table 4. Occurrence frequency of benthic macroinvertebrates found in foliar degradation in the areas of conventional (CT) and organic $(\mathrm{OF})$ systems, and natural wetland $(\mathrm{NW})$.

\begin{tabular}{|c|c|c|c|}
\hline Taxon & $\mathrm{CT}$ & $\mathrm{OF}$ & NW \\
\hline Nematode & Ad & Co & $\mathrm{Co}$ \\
\hline Ceratopogonidae & - & - & Ad \\
\hline Chaoboridae & Ad & - & - \\
\hline Chironomidae & Co & Co & Co \\
\hline Culicidae & Ad & - & Ad \\
\hline Sciomyzidae & Ad & - & - \\
\hline Syrphidae & - & - & Ad \\
\hline Tabanidae & Ad & - & - \\
\hline Tipulidae & - & - & Ad \\
\hline Dytiscidae & Ad & Ad & Ad \\
\hline Elmidae (immature) & - & 0 & Ad \\
\hline Elmidae (adult) & - & - & Ad \\
\hline Gyrinidae & - & -0 & Ad \\
\hline Haliplidae & Ad & Ac & - \\
\hline Hydrophilidae (immature) & Ad & - & Ad \\
\hline Hydrophilidae (adult) & - & - & Ad \\
\hline Hydropsychidae & - & $\mathrm{Ad}$ & - \\
\hline Hebridae & - & - & Ad \\
\hline Hydrometridae & $\mathrm{Ad}$ & - & - \\
\hline Mesoveliidae & - & - & Ad \\
\hline Saldidae & - & - & $\mathrm{Ad}$ \\
\hline Veliidae & - & - & $\mathrm{Ad}$ \\
\hline Calopterigidae & - & - & Ad \\
\hline Libellulidae & $\mathrm{Ad}$ & Ad & Ad \\
\hline Baetidae & - & $\mathrm{Ad}$ & - \\
\hline Caenidae & - & $\mathrm{Ad}$ & $\mathrm{Ac}$ \\
\hline Leptohyphidae & - & - & Ad \\
\hline Xyphocentronidae & - & - & Ad \\
\hline Collembola & $\mathrm{Ad}$ & Ad & $\mathrm{Co}$ \\
\hline Hirudinea & $\mathrm{Ac}$ & Co & Co \\
\hline Amphipoda & Co & $\mathrm{Co}$ & $\mathrm{Ad}$ \\
\hline Palaemonidae & Ad & - & - \\
\hline Acari & Ad & $\mathrm{Ad}$ & Co \\
\hline Bivalvia & - & - & Ac \\
\hline Planorbidae & Ac & - & Ad \\
\hline Physidae & - & - & $\mathrm{Ad}$ \\
\hline
\end{tabular}

Ad, accidental species (present in less than $25 \%$ of the collections); Ac, incidental species (present in less than $50 \%$, and more than $25 \%$ of the collections); and Co, constant species (present in more than $50 \%$ of the collections).
(2009), palatability depends on the hardness of leaves, and on concentrations of secondary compounds that confer resistance to tissues, which causes a slower litter decomposition. In addition, according to CunhaSantino \& Bianchini Jr. (2006), decomposition varies both because of factors related to litter - as the C:N:P ratio, material and origin, among others -, and because of external factors such as nutrient concentration, temperature, and $\mathrm{pH}$ of the environment.

The systems studied had a lower abundance of benthic macroinvertebrates than natural wetlands; and the diversity of these organisms was also reduced in the conventional system. The evaluation of phytomass degradation was sensitive to this differentiation of the environmental management, showing its effects on the functionality of this agroecosystem.

The reduction of ecosystem functions causes the declining of nutrient availability, affecting the natural processes and other services, as the maintenance of plant and animal biodiversity, thus increasing crop production costs; this way, the use of the organic management or other less impactful systems, as water management for invasive plants and integrated pest management, are recommended to provide the maintenance of the evaluated processes that may improve gains from cultivation sustainability.

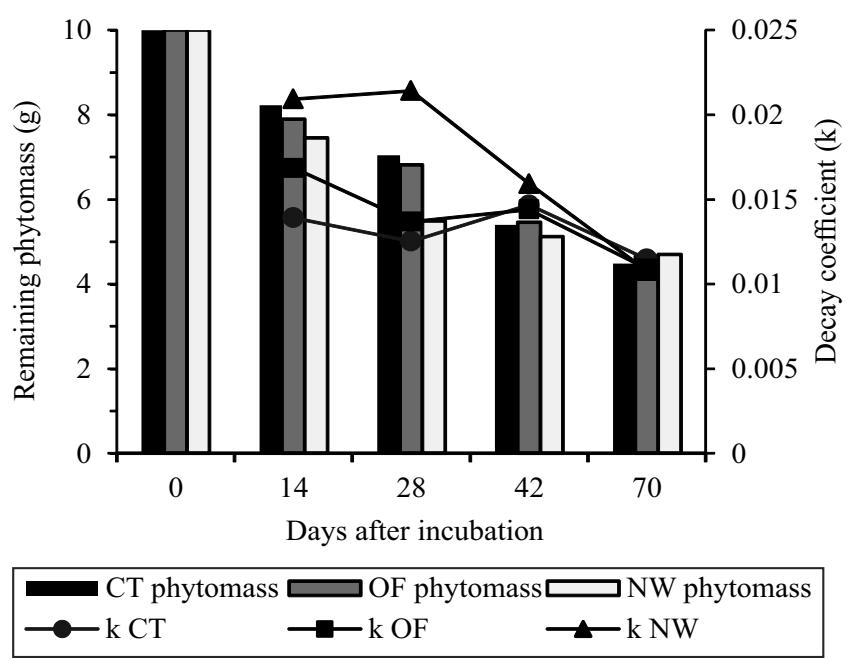

Figure 3. Decay coefficient of phytomass degradation and amount of remaining phytomass during the experiment of the studied management systems. CT, conventional system; $\mathrm{OF}$, organic system; and NW, natural wetland. 


\section{Conclusions}

1. The management systems promote differences in the colonization of rice straw by benthic macroinvertebrates.

2. The need to maintain diversity of benthic macroinvertebrates becomes clear when there is diversity loss, as observed in rice straw biomass in the site of conventional system.

3. Nutrient cycling, provided by phytomass decomposition, is affected by the management system, and the delay in this process causes a reduction of the ecosystem function in the conventional system, thus affecting its sustainability; nevertheless, 70 days after the phytomass incubation, the remaining straw is similar in all treatments, which shows a resilience ability.

\section{Acknowledgments}

To Embrapa Clima Temperado, to Fundação de Amparo à Pesquisa do Estado do Rio Grande do Sul (Fapergs), and to Conselho Nacional de Desenvolvimento Científico e Tecnológico (CNPq), for their support and scholarship granted.

\section{References}

BARBOLA, I.F.; MORAES, M.F.P.G.; ANAZAWA, T.M.; NASCIMENTO, E.A.; SEPKA, E.R.; POLEGATTO, C.M.; MILlÉO, J.; SCHÜHLI, G.S. Avaliação da comunidade de macroinvertebrados aquáticos como ferramenta para o monitoramento de um reservatório na bacia do rio Pitangui, Paraná, Brasil. Iheringia. Série Zoologia, v.101, p.15-23, 2011. DOI: $10.1590 / \mathrm{S} 0073-47212011000100002$.

BARDGETT, R.D.; PUTTEN, W.H. van der. Belowground biodiversity and ecosystem functioning. Nature, v.515, p.505511, 2014. DOI: 10.1038/nature13855.

CARVALHO, E.M.; UIEDA, V.S. Seasonal leaf mass loss estimated by litter bag technique in two contrasting stretches of a tropical headstream. Acta Limnologica Brasiliensia, v.21, p.209$215,2009$.

CUMMINS, K.W.; MERRITT, R.W.; ANDRADE, P.C.N. The use of invertebrate functional groups to characterize ecosystem attributes in selected streams and rivers in south Brazil. Studies on Neotropical Fauna and Environment, v.40, p.69-89, 2005. DOI: $10.1080 / 01650520400025720$.

CUNHA-SANTINO, M.B.; BIANCHINI JR., I. Modelos matemáticos aplicados aos estudos de decomposição de macrófitas aquáticas. Oecologia Brasiliensis, v.10, p.154-164, 2006. DOI: 10.4257/oeco.2006.1002.03.
DI SABATINO, A.; GERECKE, R.; MARTIN, P. The biology and ecology of lotic water mites (Hydrachnidia). Freshwater Biology, v.44, p.47-62, 2000. DOI: 10.1046/j.1365-2427.2000.00591.x.

GIMENES, K.Z.; CUNHA-SANTINO, M.B. da; BIANCHINI JR., I. Decomposição de matéria orgânica alóctone e autóctone em ecossistemas aquáticos. Oecologia Australis, v.14, p.10361073, 2010. DOI: 10.4257/oeco.2010.1404.13.

GROOT, R.S. de; WILSON, M.A; BOUMANS, R.M.J. A typology for the classification, description and valuation of ecosystem functions, goods and services. Ecological Economics, v.41, p.393-408, 2002. DOI: 10.1016/S0921-8009(02)00089-7.

HANDA, I.T.; AERTS, R.; BERENDSE，F.; BERG， M.P.; BRUDER, A.; BUTENSCHOEN, O.; CHAUVET, E.; GESSNER, M.O.; JABIOL, J.; MAKKONEN, M.; MCKIE, B.G.; MALMQVIST, B.; PEETERS, E.T.H.M.; SCHEU, S.; SCHMID, B.; RUIJVEN, J. van; VOS, V.C.A.; HÄTTENSCHWILER, S. Consequences of biodiversity loss for litter decomposition across biomes. Nature, v.509, p.218-221, 2014. DOI: 10.1038/ nature13247.

KERANS, B.L.; KARR, J.R. A benthic index of biotic integrity (B-IBI) for rivers of the Tennessee Valey. Ecological Applications, v.4, p.768-785, 1994. DOI: 10.2307/1942007.

KOTTEK, M.; GRIESER, J.; BECK, C.; RUDOLF, B.; RUBEL, F. World Map of the Köppen-Geiger climate classification updated. Meteorologische Zeitschrift, v.15, p.259-263, 2006. DOI: $10.1127 / 0941-2948 / 2006 / 0130$.

MASSONI, P.F.S.; MARCHESAN, E.; GROHS, M.; SILVA, L.S da; ROSO, R. Nutrientes do solo influenciados por diferentes manejos da palha após a colheita do arroz irrigado. Revista Ciência Agronômica, v.44, p.205-214, 2013. DOI: 10.1590/ S1806-66902013000200001.

MELO, S.; STENERT, C.; DALZOCHIO, M.S.; MALTCHIK, L. Development of a multimetric index based on aquatic macroinvertebrate communities to assess water quality of rice fields in southern Brazil. Hydrobiologia, v.742, p.1-14, 2015. DOI: 10.1007/s10750-014-1957-7.

MONKS, P.L.; FERREIRA, O.G.L.; GOULART, E.Q.; TERRES, A.L.S. Potencial forrageiro do arroz irrigado (Oryza sativa L.) após a colheita dos grãos. Revista Brasileira de Agrociência, v.8, p.67-70, 2002.

MORETTI, M.S.; GONÇALVES JÚNIOR, J.F.; LIGEIRO, R.; CALLISTO, M. Invertebrates colonization on native tree leaves in a neotropical stream (Brazil). International Review of Hydrobiologia, v.92, p.199-210, 2007. DOI: 10.1002/ iroh.200510957.

MORETTI, M.S.; LOYOLA, R.D.; BECKER, B.; CALLISTO, $M$. Leaf abundance and phenolic concentrations codetermine the selection of case-building materials by Phylloicus sp. (Trichoptera, Calamoceratidae). Hydrobiologia, v.630, p.199-206, 2009. DOI: 10.1007/s10750-009-9792-y.

MORMUL, R.P.; VIEIRA, L.A.; PRESSINATTE JÚNIOR, S.; MONKOLSKI, A.; SANTOS, A.M. dos. Sucessão de invertebrados durante o processo de decomposição de duas plantas aquáticas (Eichhornia azurea e Polygonum ferrugineum). 
Acta Scientiarum. Biological Sciences, v.28, p.109-115, 2006. DOI: $10.4025 /$ actascibiolsci.v28i2.1017.

MOULTON, T.P.; MAGALHÃES, S.A.P. Responses of leaf processing to impacts in streams in Atlantic rain Forest, Rio de Janeiro, Brazil - a test of the biodiversity-ecosystem functioning relationship? Brazilian Journal of Biology, v.63, p.87-95, 2003. DOI: $10.1590 / \mathrm{S} 1519-69842003000100012$.

MUGNAI, R.; NESSIMIAN, J.L.; BAPTISTA, D.F. Manual de identificação de macroinvertebrados aquáticos. Rio de Janeiro: Technical Books, 2010. 174p.

NAKAGOME, F.K.; NOLDIN, J.A.; RESGALLA JR., C. Toxicidade aguda de alguns herbicidas e inseticidas utilizados em lavouras de arroz irrigado sobre o peixe Danio rerio. Pesticidas: Revista de Ecotoxicologia e Meio Ambiente, v.17, p.117-122, 2007. DOI: $10.5380 /$ pes.v17i0.9186.

NIN, C.S.; RUPPENTHAL, E.L.; RODRIGUES, G.G. Produção de folhiço e fauna associada de macroinvertebrados aquáticos em curso d'água de cabeceira em Floresta Ombrófila do Estado do Rio Grande do Sul, Brasil. Acta Scientiarum. Biological Sciences, v.31, p.263-271, 2009. DOI: 10.4025/actascibiolsci.v31i3.355.

OLIVEIRA, A.; CALLISTO, M. Benthic macroinvertebrates as bioindicators of water quality in an Atlantic forest fragment. Iheringia. Série Zoologia, v.100, p.291-300, 2010. DOI: 10.1590/ S0073-47212010000400003.

PETERSEN, R.C.; CUMMINS, K.W. Leaf processing in a woodland stream. Freshwater Biology, v.4, p.343-368, 1974. DOI: 10.1111/j.1365-2427.1974.tb00103.x.

PILLAR, V. de P.; ORLÓCI, L. On randomization testing in vegetation science: multifactor comparisons of relevé groups. Journal of Vegetation Science, v.7, p.585-592, 1996. DOI: $10.2307 / 3236308$.

PILLAR, V.D.P. MULTIV: multivariate exploratory analysis, randomization testing and tootstrap resampling: User's Guide v. 2.1. Porto Alegre: Universidade Federal do Rio Grande do Sul, 2001. Available at: <http://ecoqua.ecologia.ufrgs.br/arquivos/ Software/Multiv/MultivManual.pdf>. Accessed on: Oct. 102015.

PIRES, M.M.; KOTZIAN, C.B.; SPIES, M.R.; BAPTISTA, V. dos A. Comparative assessment of aquatic macroinvertebrate diversity in irrigated rice fields and wetlands through different spatial scales: an additive partitioning approach. Marine and Freshwater Research, v.67, p.368-379, 2015. DOI: 10.1071/ mf14109.
RIZO-PATRÓN V., F.; KUMAR, A.; COLTON, M.B.M.; SPRINGER, M.; TRAMA, F.A. Macroinvertebrate communities as bioindicators of water quality in conventional and organic irrigated rice fields in Guanacaste, Costa Rica. Ecological Indicators, v.29, p.68-78, 2013. DOI: 10.1016/j. ecolind.2012.12.013.

RODRIGUES, W.C. DivEs - Diversidade de Espécies: an ecological software: v3.0. 2014. Available at: <http://dives.ebras. bio.br/downloads.aspx>. Accessed on: Jan. 292016.

SANTOS, I.G.A. dos; RODRIGUES, G.G. Colonização de macroinvertebrados bentônicos em detritos foliares em um riacho de primeira ordem na Floresta Atlântica do Nordeste brasileiro. Iheringia. Série Zoologia, v.105, p.84-93, 2015. DOI: 10.1590/1678-4766201510518493.

SANTOS, K.P. dos. Macroinvertebrados bentônicos e parâmetros físico-químicos como indicadores da qualidade da água de microbacias utilizadas para o abastecimento público da região metropolitana de Goiânia. 2014. 69p. Dissertação (Mestrado) - Universidade Federal de Goiás, Goiânia.

SILVEIRA, V.M. da; ANTUNES, G.M.; DIAS, M.F.P. Inovação em sistemas de produção de arroz orgânico no Rio Grande do Sul. Revista de Administração da UFSM, v.5, p.715-728, 2012. Edição especial. DOI: 10.5902/198346597782.

TELÖKEN, F.; ALBERTONI, E.F.; HEPP, L.U.; PALMA-SILVA, C. Invertebrados aquáticos associados a serapilheira de Salix humboldtiana em um riacho subtropical. Ecología Austral, v.24, p.220-228, 2014.

TELÖKEN, F.; ALBERTONI, E.F.; PALMA-SILVA, C. Leaf degradation of Salix humboldtiana Willd. (Salicaceae) and invertebrate colonization in a subtropical lake (Brazil). Acta Limnologica Brasiliensia, v.23, p.30-41, 2011. DOI: 10.4322/ actalb.2011.016.

THRUPP, L.A. Linking agricultural biodiversity and food security: the valuable role of agrobiodiversity for sustainable agriculture. International Affairs, v.76, p.265-281, 2000. DOI: 10.1111/1468-2346.00133.

WILSON, A.L.; WATTS, R.J.; STEVENS, M.M. Effects of different management regimes on aquatic macroinvertebrate diversity in Australian rice fields. Ecological Research, v.23, p.565-572, 2008. DOI: 10.1007/S11284-007-0410-z.

Received on June 7, 2016 and accepted on November 9, 2016

Pesq. agropec. bras., Brasília, v.52, n.4, p.261-270, abr. 2017

DOI: $10.1590 / \mathrm{S} 0100-204 X 2017000300006$ 